\title{
E-Government Media Informasi Alat Kelengkapan Dewan Provinsi Bali dan Media Diskusi Berbasis Website
}

\author{
Putu Sugiartawan* ${ }^{1}$, I Dewa Ketut Rai Rustina ${ }^{2}$, Rachmat Wahid Saleh Insani ${ }^{3}$ \\ ${ }^{1}$ Program Studi Teknik Informatika, STMIK STIKOM Indonesia, Bali \\ ${ }^{2}$ Humas Protokol DPRD Provinsi Bali \\ ${ }^{3}$ Fakultas Teknik Prodi Teknik Informatika, Universitas Muhammadiyah Pontianak \\ e-mail: *11 putu.sugiartawan.85@gmail.com, ${ }^{2}$ Dewa.rai@gmail.com, \\ ${ }^{3}$ rachmat.wahid@unmuhpnk.ac.id
}

\begin{abstract}
Abstrak
Perkembangan teknlogi dan informasi pada masa ini sangat lah pesat, salah satunya adalah internet. Kemudahan menggali informasi melalui website mendorong lembaga negara untuk menggunakan website sebagai media informasi kepada publik. Tujuan diadakannya penelitian ini adalah untuk membangun dan merancang E-Gov media informasi di DPRD Provinsi Bali yang digunakan sebagai media informasi dan diskusi yang dapat dimanfaatkan oleh masyarakat maupun dewan. Konten website hanya menampilkan informasi tentang dewan seperti alat kelengkapan dewan dengan sub bagian sebagai berikut; Pimpinan Dewan, Komisikomisi, Bamus, Banggar, Baleg, Badan Kehormatan. Serta memungkinkan pengunjung website untuk dapat menyampaikan aspirasi terhadap dewan
\end{abstract}

Kata kunci- e-government, media informasi, website

\begin{abstract}
The development of technology and information at this time is very fast, one of which is the internet. The ease of digging information through a website encourages state institutions to use the website as a medium of information to the public. The purpose of this research is to build and design E-Gov media information in the DPRD of the Province of Bali which is used as a medium of information and discussion that can be utilized by the community and the council. Website content only displays information about the board such as board fittings with the following sub-sections; Leadership of the Board, Commissions, Bamus, Banggar, Baleg, Honorary Board. As well as allowing website visitors to be able to express aspirations to the board
\end{abstract}

Keywords-e-government, medium of information, website

\section{PENDAHULUAN}

Perkembangan teknlogi dan informasi pada masa ini sangat lah pesat, salah satunya adalah internet. Internet merupakan jaringan global yang menghubungkan komputer-komputer seluruh dunia. Dengan adanya internet, sebuah komputer dapat mengakses data yang terdapat pada komputer lain di benua yang berbeda. Internet menjadi sarana untuk mendapatkan dan menyebarkan informasi secara cepat. Pada tahun 1982 istilah "internet" pertama kali digunakan, dan TCP/IP diadopsi sebagai protokol universal untuk jaringan trsebut.

World Wide Web (www) adalah program yang ditemukan oleh Tim Berners-Lee pada tahun 1991. Awalnya Berners-Lee hanya ingin menemukan cara untuk menyusun arsip-arsip risetnya. Untuk itu, beliau mengembangkan suatu sistem untuk keperluan pribadi. Program yang 
ISSN (print): 2655-2183, ISSN (online): 2655-7290

dibuat Berners-Lee tersebut terus disempurnakan hingga sekarang menjadi program yang sering kita gunakan yakni www. Website (situs web) adalah suatu halaman web yang saling berhubungan yang umumnya berada pada web server yang sama berisikan kumpulan informasi yang disediakan secara perorangan, kelompok, atau organisasi. Pemanfaatan teknologi informasi untuk mengurangi human error dan meningkatkan efiktifitas kerja [1]. Selain sistem informasi (SI), perkembangan internet merambah pada sistem pendukung keputusan secara kelompok (SPKK). Pemanfaatan SPKK dapat meningkatkan pengambilan keputusan dari berbagai instansi ataupun individu [2]. Layanan informasi berbasis web di dalam lembaga pemerintahan dan warga negara menyediakan berbagai jenis informasi publik untuk mendukung pengambilan keputusan [3]-[5]. Namun, warga negara memiliki perbedaan lingkungan akses informasi, kemampuan memahami informasi dan keinginan pengejaran informasi, dan sebagainya, sehingga mereka memiliki kesenjangan informasi[3], [6]. Secara umum, interaksi antara warga negara dan lembaga pemerintah terjadi di kantor pemerintah. Dengan teknologi informasi dan komunikasi yang muncul, dimungkinkan untuk menemukan pusat layanan yang lebih dekat dengan masyarakat [7], [8]. Pusat-pusat tersebut dapat terdiri dari kios yang tidak dijaga di lembaga pemerintah, kios layanan yang terletak dekat dengan klien, atau penggunaan komputer pribadi di rumah atau kantor [9], untuk menentukan kekuatan dan lemahan penggunaan e-gov, digunakan SWOT analysis [10].

Kemudahan menggali informasi melalui website mendorong lembaga negara untuk menggunakan website sebagai media informasi kepada publik. Tujuan akhir dari e-government adalah membangun platform yang mewakili gambaran pemerintah [11]. Perkembangan menunjukkan bahwa program layanan berbasis informasi meningkat dengan intrusi yang dideritanya. Oleh karena itu, perlindungan e-government memiliki persyaratan keamanan yang sangat tinggi[11]. Selain itu sistem dapat mengurangi biaya administrasi sambil meningkatkan pengawasan dan pemerintah standar pelayanan publik [12]. Ada banyak dimensi kualitas, dan masing-masing memiliki ukuran yang berkaitan dengan situs web tertentu dalam berbagai hal [11][13]. Berikut adalah beberapa di antaranya: waktu, situs yang kredibel harus sering diperbarui. Informasi tentang pembaruan terbaru juga harus dimasukkan di halaman utama [13]. Setiap pemangku kepentingan e-government benar-benar menggunakan situs web pemerintah untuk mengejar insentif materialnya sendiri dan jarang mengharapkan reformasi dan edemokrasi pemerintah [14].

Begitu juga dengan Dewan Perwakilan Rakyat Daerah (DPRD) Provinsi Bali membutuhkan sebuah media informasi berupa E-Gov dimana masyarakat dapat mengakses informasi tentang dewan seperti alat kelengkapan dewan dan sebagai media untuk masyarakat menyampaikan aspirasinya terhadap kinerja dewan. Masyarakat dapat mengetahui struktur kepengurusaan dari alat kelengkapan dewan tersebut seperti pimpinan dewan, pimpinan komisikomisi, serta pimpinan dari alat kelengkapan dewan yang lain. Dengan adanya E-Gov masyarakat dapat dengan mudah untuk mendapatkan informasi dimanapun dan kapanpun. Bagian Humas dan Protokol di Sekretariat DPRD Provinsi Bali merupakan fasilitator dalam penyampaian aspirasi dari masyarakat kepada DPRD dalam setiap proses pembuatan keputusan yang dijadikan suatu kebijakan di masyarakat dan itu harus dipublikasikan melalui media.

Sehubungan dengan hal tersebut diatas, maka penulis akan mengadakan penelitian untuk membangun sebuah E-Gov Media Informasi Alat Kelengkapan DPRD Provinsi Bali dan Media Diskusi Berbasis Web yang akan dapat diakses secara online.

\section{METODE PENELITIAN}

\subsection{Gambaran Umum DPRD Prov. Bali}

Penulisan pada Berdasarkan Undang-Undang nomor 64 Tahun 1954 dan UndangUndang Nomor 1 Tahun 1992 menjelaskan bahwa Pemerintahan Provinsi Bali terdiri dari 8 Kabupaten dan 1 Kota yakni Kabupaten Badung, Kabupaten Tabanan, Kabupaten Jembrana, Kabupaten Buleleng, Kabupaten Karangasem, Kabupaten Bangli, Kabupaten Klungkung,

JSIKTI Vol. 1, No. 2, December 2018: $75-86$ 
Kabupaten Gianyar, dan Kota Madya Denpasar. Disamping struktur pemerintahan yang resmi di Bali juga terdapat pemerintahan tradisional yang ekstensinya tetap diakui yang berdasarkan adat, dimana dalam pelaksaan tugasnya saling menunjang, yaitu Desa Adat dan Banjar disamping organisasi kemasyarakatan tradisional lainnya seperti Subak dan Sekehe-sekehe, yang justru sebagai pemacu terlaksananya berbagai program pemerintahan dengan hasil yang optimal.

Gedung DPRD Bali perencanaan pembangunannya di mulai sejak tahun anggaran 19821983 dan peletakan batu pertamanya dilaksanakan pada tahun 1983 oleh Gubernur Bali Ida Bagus Mantra didampingi oleh Ketua Dewan H.Soekidjo Digdowiratmo pada saat itu. Karena terbatasnya dana, maka pembangunan dilaksanakan secara bertahap dan selesai pada bulan agustus 1998. Tujuan pembangunan gedung DPRD Provinsi Bali adalah sebagaimana penyaluran aspirasi atas dasar demokrasi dengan pedoman pada landasan pancasila dan undangundang dasar 1945. Sasarannya adalah secara fisik dapat memenuhi tuntunan kegiatan baik secara kualitas maupun kuantitas, dan secara non fisik mampun mengucapkan simbul fungsi dan kedudukan dalam sistem pemerintahan daerah dan juga mengungkapkan nilai-nilai aspirasi masyarakat.

Berdasarkan kegiatan dan konsep Arsitektur Tradisional Bali, yang bertujuan untuk mewujudkan hubungan kerjasama yang serasi, selaras dan penuh tanggung jawab, maka perwujudan dan pengguanaan bangunan dikelompokan menjadi 3 unit yaitu: Utama Mandala, Madya Mandala, dan Nista Mandala, seperti Gambar 1.

Pada bagian Humas dan Protokol memiliki struktur organisasi yang bertujuan untuk mempermudah dan memperlancar pelaksanaan tugas dan tanggung jawab masing-masing. Berikut adalah struktur organisasi pada bagian Humas dan Protokol:

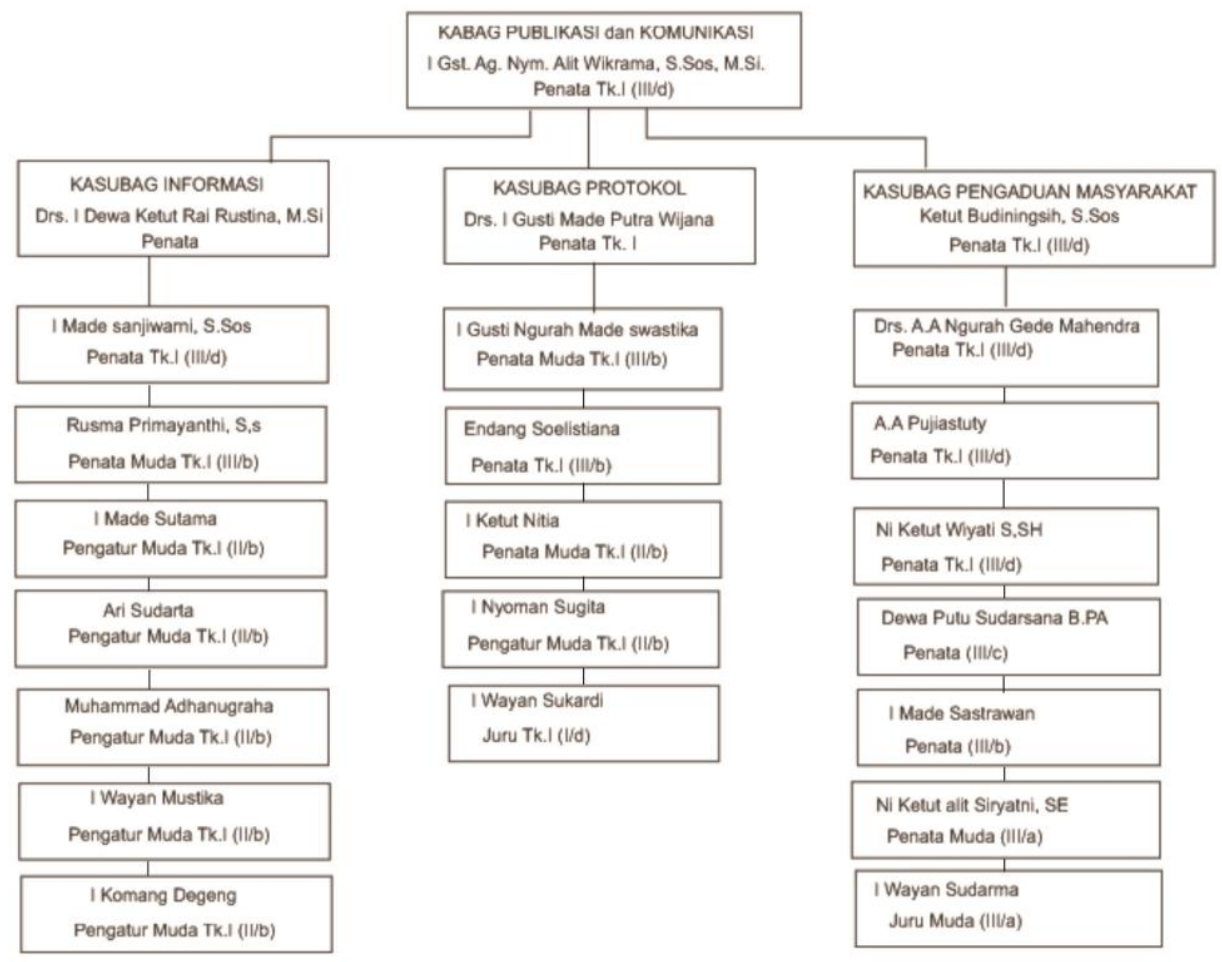

Gambar 1. Struktur Organisasi Humas dan Protokol

\section{2 Media}

Media adalah segala bentuk dan saluran yang digunakan untuk menyampaikan informasi atau pesan. Kata media berasal dari kata latin, merupakan bentuk jamak dari kata medium. Secara harfiah kata tersebut mempunyai arti perantara atau pengantar, yaitu perantara 
sumber pesan (a source) dengan penerima pesan (a receiver). Jadi, dalam pengertian yang lain, media adalah alat atau sarana yang dipergunakan untuk menyampaikan pesan dari komunikator kepada khalayak.

Media merupakan salah satu komponen dalam proses komunikasi. Selain media, beberapa komponen lain dalam proses komunikasi adalah sumber informasi, pesan, penerima dan tujuan. Proses komunikasi tidak akan berjalan dengan lancar apabila salah satu dari komponen diatas tidak ada. Seiring dengan berkembangnya teknologi informasi dan komunikasi, media semakin berkembang dari segi bentuk dan cara dalam menyajikannya.

Media Visual merupakan jenis media yang bisa dilihat, dibaca dan diraba. Media ini mengandalkan indra penglihatan dan peraba. Berbagai jenis media ini sangat mudah untuk didapatkan. Contoh media yang sangat banyak dan mudah untuk didapatkan maupun dibuat sendiri. Contoh: media foto, gambar, komik, gambar tempel, poster, majalah, buku, miniatur, alat peraga, website dan sebagainya. Selain media visual ada juga jenis media yang lain yaitu media audio dan media audio visual.

\section{3 Informasi}

Secara umum informasi dapat didefinisikan sebagai hasil dari pengolahan data dalam suatu bentuk yang lebih berguna dan lebih berarti bagi penerimanya yang menggambarkan suatu kejadian-kejadian yang nyata yang digunakan untuk pengambilan keputusan. Informasi menjadi penting, karena berdasarkan informasi para pengelola dapat mengetahui kondisi obyektif sebuah perusahaan atau instansi tertentu. Informasi tersebut merupakan hasil pengolahan data atau fakta yang dikumpulkan dengan metode ataupun cara-cara tertentu.

Informasi dapat didefinisikan sebagai hasil dari pengolahan data dalam suatu bentuk yang lebih berguna dan lebih berarti bagi penerimanya yang menggambarkan suatu kejadian kejadian (event) yang nyata (fact) yang digunakan untuk pengambilan keputusan [15]. Informasi adalah data yang telah diproses sedemikian rupa sehingga meningkatkan pengetahuan seseorang yang telah menggunakan data tersebut [16][17]. Informasi merupakan data yang telah diolah menjadi sebuah bentuk yang berarti bagi penerimanya dan bermanfaat dalam pengambilan keputusan untuk saat ini atau di masa mendatang [18].

Informasi yang berkualitas memiliki ciri-ciri sebagai berikut:

1. Relevan, Informasi yang disajikan sebaiknya terkait dengan keputusan yang akan diambil oleh pengguna informasi tersebut.

2. Akurat, Kecocokan antara informasi dengan kejadian-kejadian atau objek-objek yang diwakilinya.

3. Lengkap, Merupakan derajat sampai seberapa jauh informasi menyertakan kejadiankejadian atau objek-objek yang berhubungan.

4. Dapat dipahami, Hal tersebut terkait dengan bahasa dan cara penyajian informasi agar pengguna atau penerima informasi lebih mudah mengambil keputusan.

5. Dapat dibandingkan, Sebuah informasi yang memungkinkan seorang pemakai untuk mengidentifikasi persamaan dan perbedaan antara dua objek yang mirip. Misalnya membandingkan laporan hasil kinerja sebuah instansi pada tahun 2013 dan 2014.

Informasi memiliki tujuan untuk mengurangi ketidak pastian dalam pengambilan keputusan dan menggambarkan keadaan yang sebenarnya dari suatu hal. Suatu informasi dapat dikatakan bernilai jika informasi tersebut dapat memberikan manfaat yang efektif bagi penerimanya.

Secara sederhana informasi merupakan data yang diolah. Data sendiri merupakan sesuatu yang belum memiliki arti bagi penerimanya dan masih membutuhkan adanya suatu pengolahan. Data dapat berwujud suatu kondisi atau keadaan, suara, huruf, simbol, gambar, angka, ataupun bahasa lainnya yang dapat digunakan sebagai bahan untuk melihat objek, lingkungan, kejadian ataupun suatu konsep.

JSIKTI Vol. 1, No. 2, December 2018: $75-86$ 


\section{4 Website Dinamis}

Citra Website atau situs dapat diartikan sebagai kumpulan halaman yang menampilkan informasi data teks, data gambar diam atau gerak, data animasi, suara, video dan atau gabungan dari semuanya, baik yang bersifat statis maupun dinamis yang membentuk satu rangkaian bangunan yang saling terkait dimana masing-masing dihubungkan dengan jaringan-jaringan halaman (hyperlink).

Word Wide Web (WWW) atau biasa disebut dngan web merupakan salah satu sumber daya yang berkembang pesat. Saat ini, informasi berupa web didistribusikan melalui pendekatan hyperlink, yang memungkinkan suatu teks, gambar ataupun objek yang lain menjadi acuan untuk membuka halaman web. Dengan pendekatan hyperlink ini, seseorang dapat memperoleh informasi dengan mengunjungi dari satu halaman ke halaman yang lain.

Website dinamis adalah website yang isi kontennya sudah termanajemen, dengan kata lain sudah menerapkan sistem content management system untuk informasi yang disampaikannya. End-user bisa sewaktu-waktu meng-update konten pada halaman website tanpa perlu paham sintax ataupun bahasa pemrograman. Melihat dari segi fungsionalitasnya, website seperti inilah yang sekarang banyak digunakan.

Website Company Profile adalah bagian dari website dinamis yang menurut fungsi dan informasi yang disampaikan. Meskipun banyak website company profile dibuat dengan website statis. Namun seiring perkembangan zaman, website company profile sudah beralih dari website statis menjadi website dinamis. Salah satu alasannya supaya data dan informasi dapat diubah kapanpun, tanpa web programmer untuk meng-update konten dari web tersebut. Selain itu, sekarang ini website company profile sudah terhubung ke situs lain seperti jejaring sosial, fungsinya agar website tersebut lebih mudah untuk diakses dan lebin banyak diketahui oleh publik.

\section{5 Content Management System (CMS)}

Dalam Content Management System (CMS) atau Sistem Manajemen Konten adalah sebuah perangkat lunak sistem komputer yang memungkinkan penerbitan, pengeditan, dan modifikasi konten serta pemeliharaan situs dari suatu halaman pusat. CMS menyediakan koleksi prosedur yang digunakan untuk mengatur dan mengelola alur kerja dalam suatu lingkungan yang kolaboratif. Prosedur-prosedur tersebut bisa saja manual, atau pun yang berbasis komputer.

1. Fitur utama atau fitur wajib pada CMS

a. Memungkinkan sejumlah besar orang untuk berbagi dan

b. berkontribusi pada data yang tersimpan.

c. Mengontrol akses data berdasarkan peran user-nya.

d. Memfasilitasi penyimpanan dan pengambilan data.

e. Mengontrol kebenaran dan kesesuaian data.

f. Mengurangi duplikasi input.

g. Menyederhanakan pembuatan dan penulisan laporan.

h. Meningkatkan komunikasi di antara penggunanya.

i. Mampu mengenali semua jenis data, seperti dokumen,

j. gambar, video, teks, nomor telepon, dan lain-lain.

2. Fungsi atau Kegunaan CMS

Berdasarkan dari fungsi dan kegunaannya, CMS dikategorikan dalam 2 jenis, yaitu:

a. Enterprise CMS (ECM), adalah suatu perangkat lunak CMS yang biasa digunakan dalam suatu perusahaan, yang mampu membantu kinerja dan produksi perusahaan, dan lain-lain.

b. Web CMS, adalah suatu paket aplikasi atau pun aplikasi stand-alone yang digunakan untuk membuat, mengelola, menyimpan, dan menyebarkan konten pada suatu halaman Web. 


\section{6 Pengumpulan Data}

Metode pengumpulan data yang digunakan dalam penelitian ini adalah metode primer dan sekunder.

\subsubsection{Metode Pengumpulan Data Primer}

Metode pengumpulan data primer adalah metode pengumpulan data yang didapat langsung dari sumbernya. Metode pengumpulan data primer dapat dibagi 2 yaitu :

1. Metode Wawancara

Merupakan metode pengumpulan data dengan berbicara langsung atau wawancara kepada narasumber. Konsultasi dengan pihak instansi yang bersangkutan untuk mendapatkan data yang lengkap mengenai objek penelitian yang akan diolah. Pada penelitian ini wawancara dilakaukan dengan narasumber Kepala Bagian Publikasi dan Komunikasi DPRD Provinsi Bali yang bernama I Gst A.Nym Alit Wikrama,S.Sos, M.Si.

2. Metode Observasi

Melakukan pengamatan secara langsung dengan mengikuti aktifitas atau kegiatan apa saja yang dilakukan di kantor Sekretariat DPRD Provinsi Bali. Dengan meneliti secara langsung, penulis memperoleh informasi dari permasalahan yang terjadi pada bagian Publikasi dan Komunikasi, terutama yang berhubungan dengan media informasi untuk msayarakat luas.

\subsubsection{Metode Pengumpulan Data Sekunder}

Merupakan metode pengumpulan data yang diperoleh dari berkas-berkas milik perusahaan dan juga buku yang sekiranya dapat dijadikan penunjang dalam suatu penelitian. Metode pengumpulan data sekunder dapat dibagi 2 yaitu:

1. Metode Dokumentasi

Dalam penelitian ini dokumentasi berupa berkas-berkas yang didapat langsung dari bagian Publikasi dan Komunikasi berupa data anggota dewan dan dokumentasi didapat juga dengan langsung memotret gambar-gambar yang terkait dengan penelitian ini.

2. Metode Kepustakaan

Merupakan pengumpulan data dengan mengambil dari buku-buku yang dapat menunjang penelitian. Adapun buku yang dipergunakan dalam penelitian ini adalah buku yang membahas tentang website, media informasi, dan teori perancangan system.

\section{7 Use Case Diagram System E-Gov.}

Use Case Diagram merupakan suatu diagram yang merepresentasikan segala hal yang bisa dilakukan sistem. Pada Gambar 1 menunjukkan aktifitas apa saja yang dapat dilakukan user kepada sistem, user yang dimaksud adalah admin dan pengunjung. Pada sistem ini admin dapat melakukan login, mengelola informasi, membuat topik, mengomentari topik dan menghapus topik. Sedangkan pengunjung hanya dapat melakukan aktifitas melihat informasi, membuat topik, serta mengomentari topik.

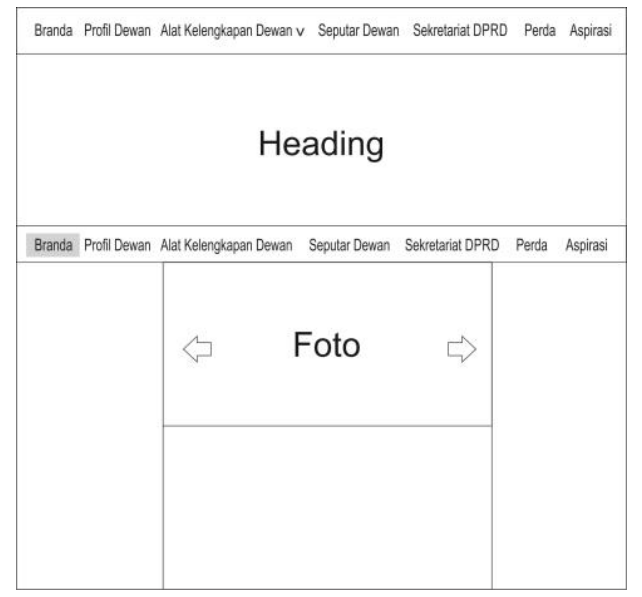

Gambar 2 User interface Halaman Beranda

JSIKTI Vol. 1, No. 2, December 2018: $75-86$ 


\subsection{Pengertian E-Government}

Pengembangan E-Government berdasarkan Inpres No. 3 Tahun 2003 adalah upanya untuk mengembangkan penyelenggaraaan kepemerintahan yang berbasis (menggunakan) elektronik dalam rangka meningkatkan kualitas layanan publik secara efektif dan efesien [19], [20]. Untuk mengembangkan sistem manajemen dan memanfaatkan kemajuan teknologi informasi maka pemarintah harus segara melaksanakan proses transformasi E-government[21], [22]. Melalui pengembangan E-Government dilakukan penataan sistem manajemen dan proses kerja dilingkungan pemerintah dengan cara :

1. Mengoptimalkan pemanfaatan kemajuan teknologi informasi untuk mengeliminasi sekat-sekat organisai dan birokrasi

2. Membentuk jaringan sistem manajemen dan proses kerja yang memungkinkan instansiinstansi pemerintah berkerja secara terpadu, untuk menyederhanakan akses kesemua informasi layanan publik yang harus disediakan oleh pemerintah.

Ada banyak manfaat yang dapat dirasakan oleh pemerintah yang melaksanakan proses transformasi menuju E-Government, diantaranya adalah sebagai berikut:

1. Memperbaiki kualitas pelayanan pemerintah kepada para stake holdernya baik masyarakat maupun kalangan bisnis dan industri;

2. Meningkatkan transfaransi, kontrol dan akuntabilitas penyelenggaraan pemerintah;

3. Mengurangi biaya administrasi relasi dan interaksi;

4. Memberiakan peluang bagi pemerintah untuk mendapatkan sumberpendapatan baru;

5. Menciptakan suatu lingkungan masyarakat informasi yang dapat secara cepat dan tepat menjawab berbagai permasalahan yang dihadapi

6. Memberdayakan masyarakat dan pihak-pihak lain sebagai mitra pemerintah dalam proses pengambilan berbagai kebijakan publik secara demokrasi.

Konsep E-Government berkembang di atas kecendrungan keinginan masyarakat untuk dapat bebas memilih bilamana dan dimana mereka inginberhubungan dengan pemerintahnya, serta bebas memilih berbagai akses yang sifatnya tradisional maupun moderen

\section{9 Rancangan Media e-Gov.}

Pada Gambar 2 merupakan user interface atau rancangan antar muka halaman beranda. Isi dari halaman ini adalah semua menu dari website dan menampilkan berita yang telah diposting kedalam website. Pada Gambar 3 merupakan user interface atau rancangan antar muka halama aspirasi. Dimana pada halaman ini pengunjung atau admin dapat membuat melihat atau membuat topik yang nantinya dapat dikomentari.

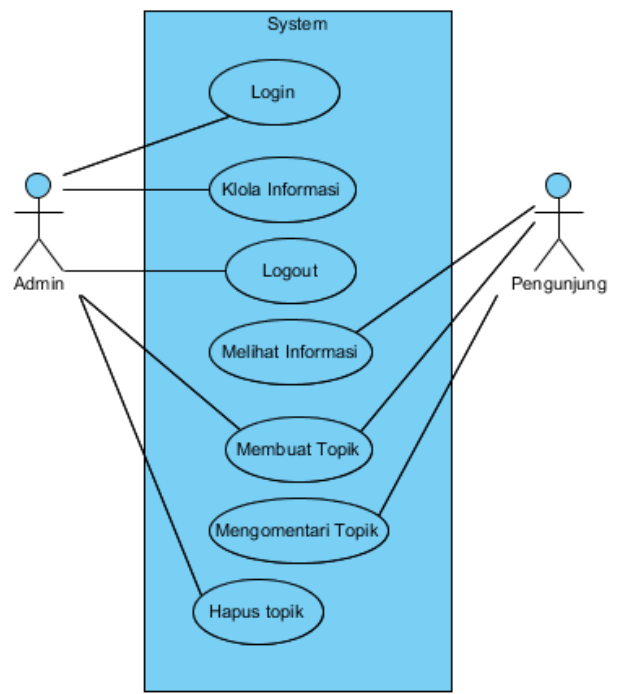

Gambar 3. User interface Halaman Beranda 


\section{HASIL DAN PEMBAHASAN}

Pada bagian ini akan membahas halaman-halaman yang terdapat dalam website DPRD Provinsi Bali yang sudah dibangun. Tampilan setiap halaman akan dibagi menjadi dua bagian, yaitu header dan content (isi). Pada bagian header berisi nama instansi. Pada bagian content (isi) berisikan halaman dan deskripsi lainnya pada suatu halaman tertentu. Tampilan semua halaman website yang dibangun sama antara satu dengan yang lain, hanya saja dalam bagian isi yang berbeda dan berubah-ubah sesuai dengan pilihan user, ditunjukan pada Gambar 4.

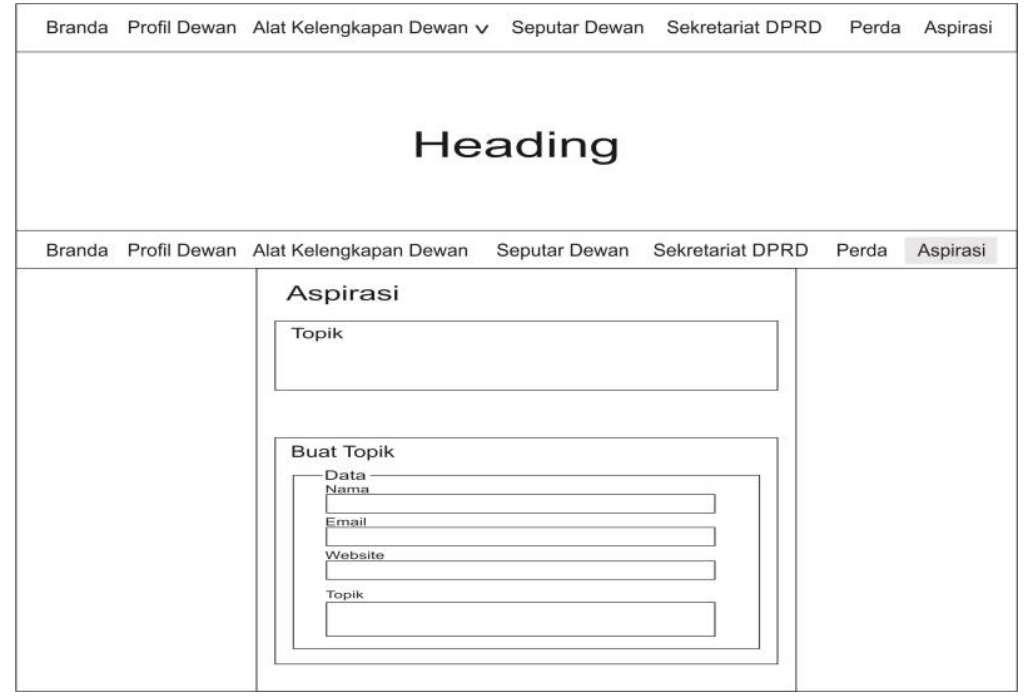

Gambar 4. User interface Aspirasi

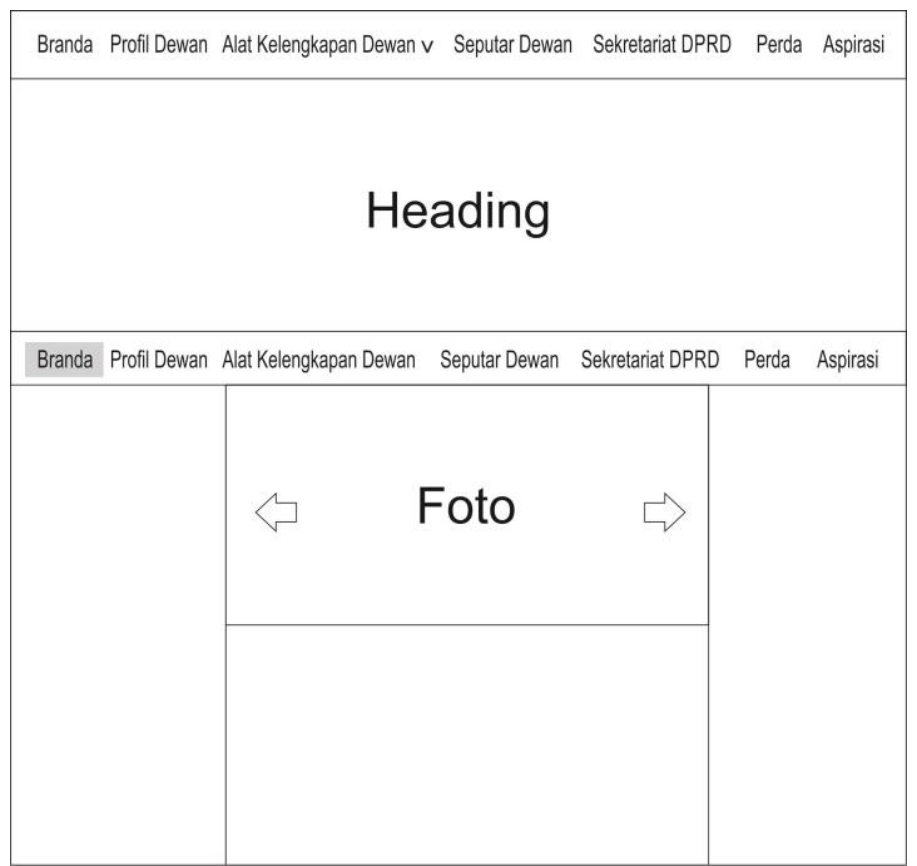

Gambar 5 User interface halaman beranda

Pada Gambar 5 merupakan user interface atau rancangan antar muka halaman beranda. Isi dari halaman ini adalah semua menu dari website dan menampilkan berita yang telah diposting kedalam website.

JSIKTI Vol. 1, No. 2, December 2018 : $75-86$ 


\subsection{Tampilan Halaman Login dan Admin}

Pada Gambar 6 merupakan tampilan halaman login yang di khususkan untuk admin untuk dapat masuk ke halaman admin agar dapat mengelola web melalui halaman tersebut.

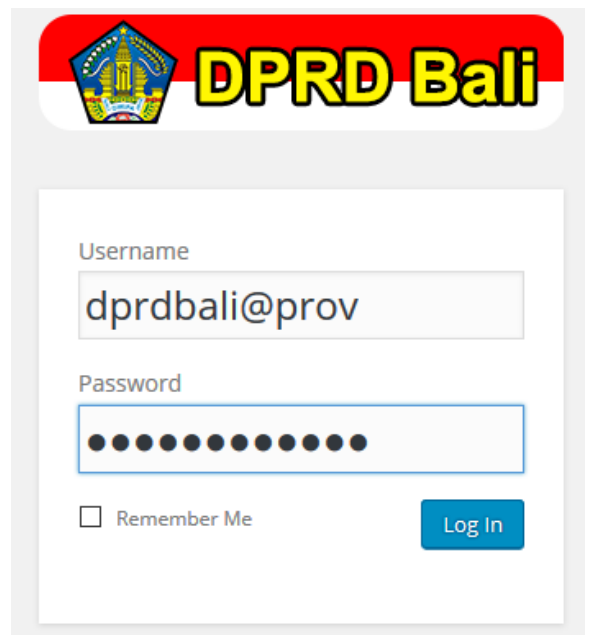

Gambar 6. Tampilan Halaman Login Admin

Pada Gambar 7 merupakan tampilan halaman Admin. Halaman ini merupakan halaman yang muncul setelah admin melakukan login. Pada halaman ini admin dapat mengelola web seperti; menghapus, menambah atau mengedit isi dari web tersebut.

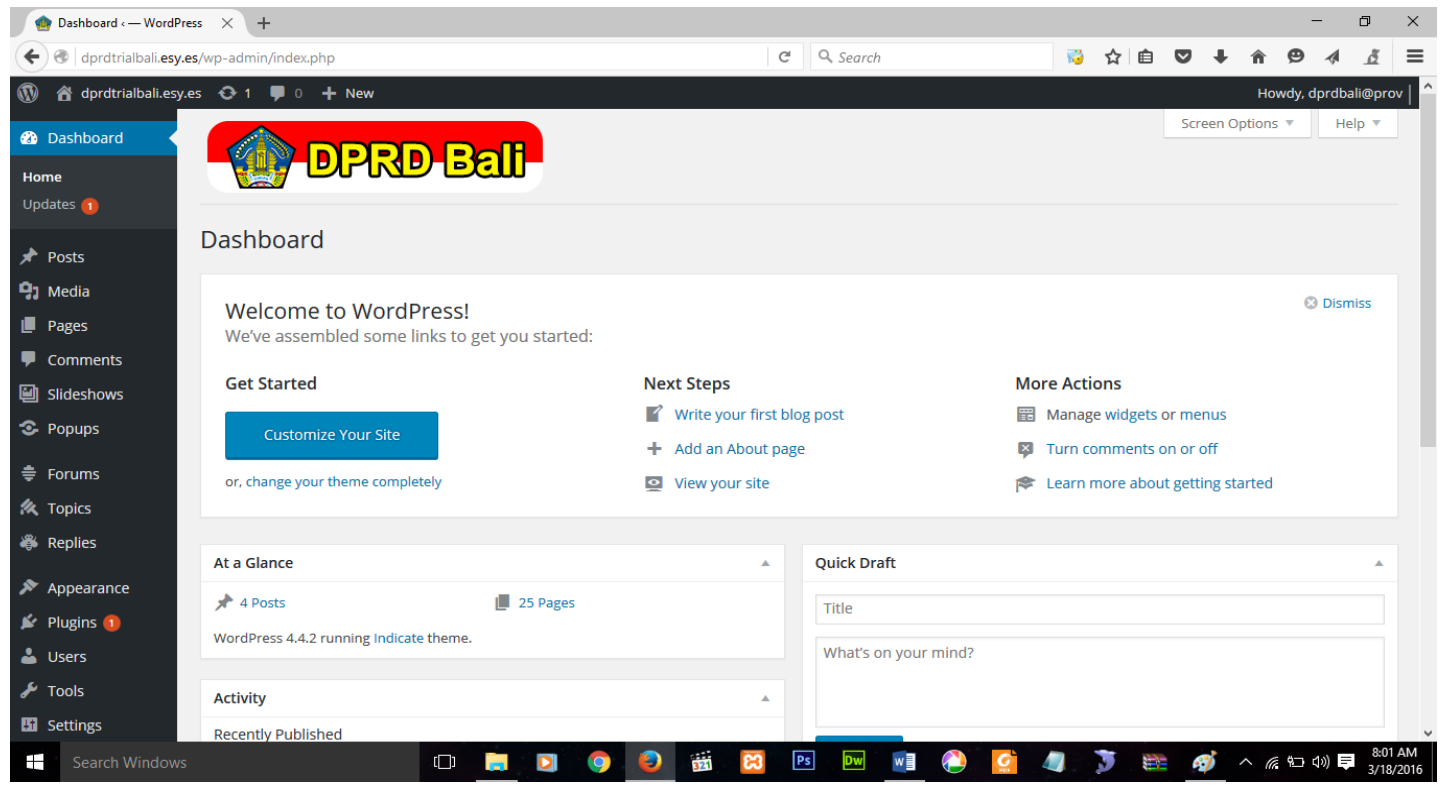

Gambar 7 Tampilan Halaman Admin

\subsection{Tampilan Halaman Alat Kelengkapan Dewan}

Pada Gambar 8 merupakan tampilan halaman web jika kengunjung menyorot atau mengarahkan mouse/pointer ke menu alat kelengkapan dewan. 


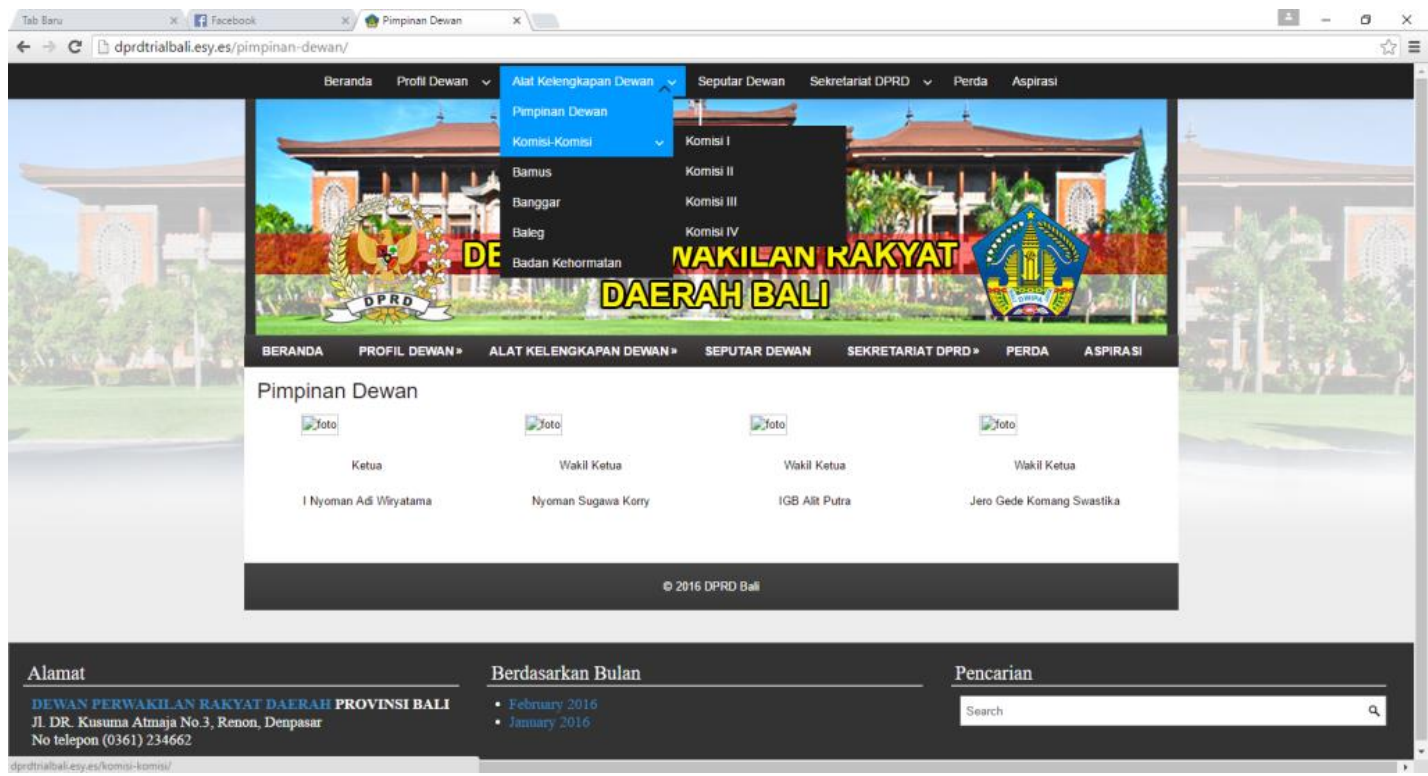

Gambar 8. Tampilan Halaman Alat Kelengkapan Dewan

Pada Gambar 9 merupakan tampilan halaman Badan Musyawarah (bamus). Pada halaman ini menampilkan informasi tentang tugas dan tujuan dari bamus dan berisikan nama anggota dan nama ketua serta wakilnya yang dilengkapi dengan photo ketua dan wakilwakilnya.

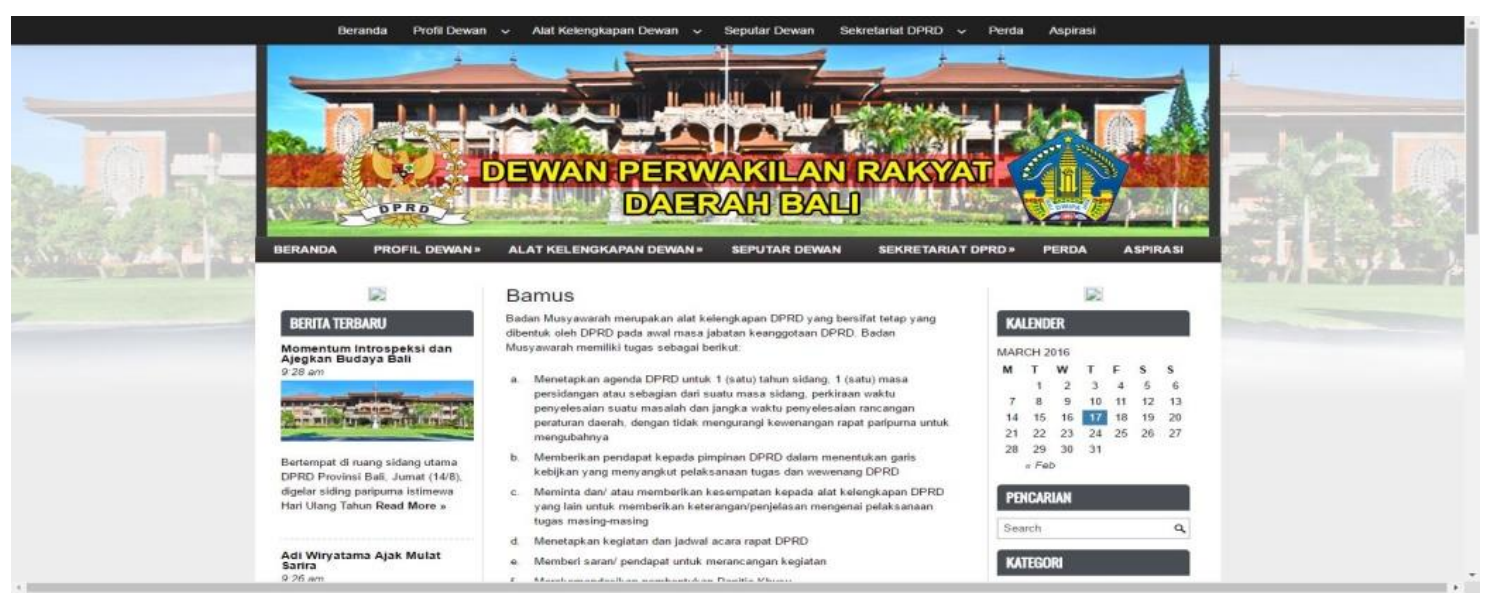

Gambar 9. Tampilan Halaman Alat Kelengkapan Dewan

\subsection{Tampilan Halaman Aspirasi}

Pada Gambar 10 merupakan tampilan halaman Aspirasi. Dimana admin dan pengunjung dapat membuat sebuah topik yang nantinya dapat saling berkomentar pada topik terebut. Halaman komentar merupakan bagian dari halaman aspirasi dimana topik yang telah dibuat dalam halaman aspirasi akan dapat di klik dan memasuki halaman komentar ini untuk para pengunjung atau pun admin dapat menyampaikan pendapatnya tentang topik yang telah dibuat. 


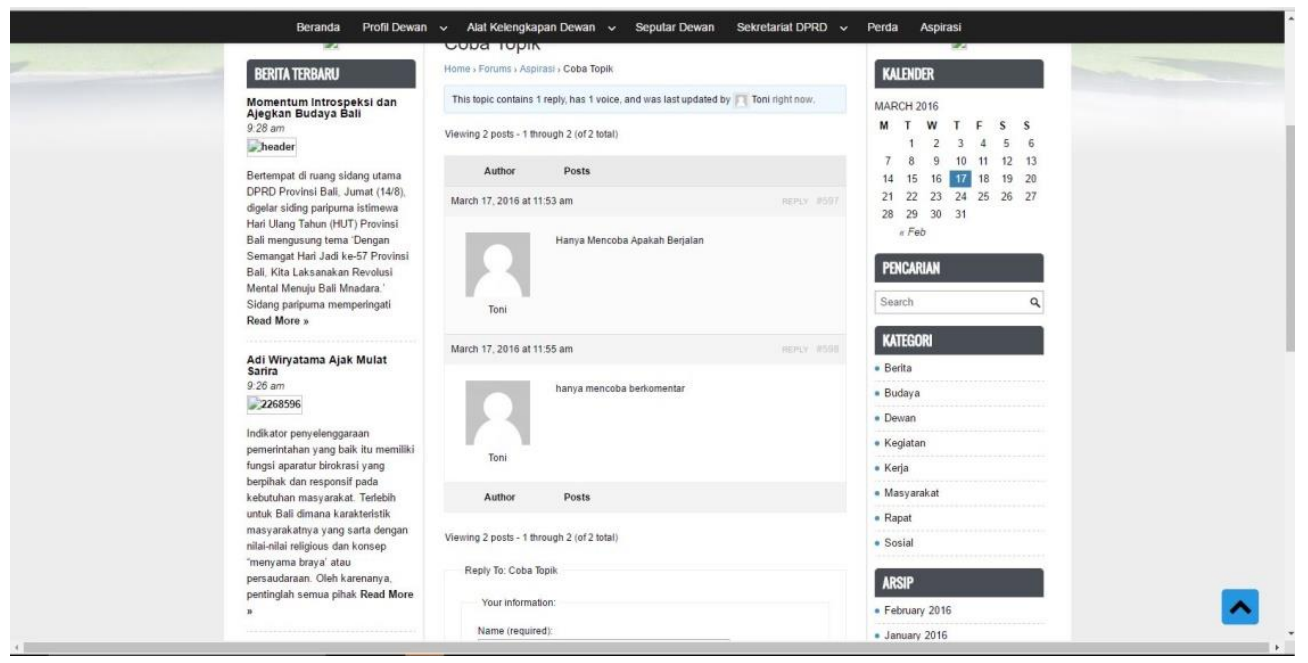

Gambar 10. Tampilan halaman aspirasi

\section{KESIMPULAN}

Hasil Dari pelaksanaan kerja praktek ini, mulai dari pengumpulan data, perancangan, pembangunan sampai implementasi dapat ditarik kesimpulan yaitu Dengan website yang dibangun ini, pada Bagian Publikasi dan Komunikasi Sekretariat DPRD Provinsi Bali akan sangat dibantu dalam hal penyampain informasi kepada masyarakat yang nantinya dapat diakses oleh masyarakat kapan saja dan dimana saja.

\section{SARAN}

Perancangan dan pembangunan website ini tentunya masih banyak kekurangan, baik itu dari segi content website, layout, dan yang lainnya. Penulis berharap untuk selanjutnya ada yang menambahkan atau meperbaharui website sejenis ini, dengan memperbaharui design yang lebih modern, content yang lebih lengkap, dan halaman yang lebih menarik.

\section{DAFTAR PUSTAKA}

[1] M. Aminudin, "Peramalan Cuaca Kota Surabaya Tahun 2011 Menggunakan Metode Moving Average dan Klasifikasi Naive Bayes," Surabaya, 2011.

[2] A. Mauko, B. Muslimin, and P. Sugiartawan, "Sistem Pendukung Keputusan Kelompok Dalam Pemilihan Saham Indeks LQ 45 Menggunakan Metode," J. Sist. Inf. dan Komput. Terap. Indones., vol. 1, no. 1, pp. 25-34, 2018.

[3] L. Dawei, "Models on Web-based information gap between e-goverment and citizens," 2008 ISECS Int. Colloq. Comput. Commun. Control. Manag., vol. 3, pp. 156-160, 2008.

[4] A. Hplunudin, Kebijakan, Birokrasi, dan Pelayanan Publik. Yogyakarta: Calpulis, 2017.

[5] Z. Mukarom and W. Muhibudin, Membangun Kinerja Pelayanan Publik Menuju Clean Government dan Good Government. Bandung: Pustaka Setia, 2016.

[6] W. Wu, "Government Transparency and Perceived Social Equity: Assessing the Moderating Effect of Citizen Trust in China," Adm. Soc., vol. 49, pp. 882-906, 2017.

[7] M. P. Damanik and E. H. Purwaningsih, "E-Government dan Aplikasinya di Lingkungan Pemerintah Daerah,” J. Stud. Komun. dan Media, vol. 21, no. 2, pp. 151-164, 2017.

[8] A. B. Mardahayati, "Kebijakan Sistem Pemerintah E-Goverment di Kabupaten Tulungagung," J. Ilm. Adm. Publik, vol. 1, no. 1, pp. 1-11, 2013.

[9] S. Pankaj, Electronic governance. India: A.P.H Publishing Coropration, 2004.

[10] I. Al-mayahi and S. P. Mansoor, "UAE E- Goverment: SWOT analysis and TOWS 
Matrix," 2012 Tenth Int. Conf. ICT Knowl. Eng., pp. 201-204, 2012.

[11] S. Xia, J. Zhang, J. Yang, and J. Ni, "2009 Fourth International Conference on Internet Computing for Science and Engineering A Content-based Self-feedback E-Government Network Security Model,” 2009 Fourth Int. Conf. Internet Comput. Sci. Eng., pp. 194198, 2010.

[12] Y. Min, "On the Current Situation of Local E-governments Based on a sample survey of 6 provinces in China," 2010 Int. Conf. E-bus. E-Government, pp. 497-500, 2010.

[13] H. Jati and D. D. Dominic, "Quality Evaluation of E-Government Website Using Web Diagnostic Tools : Asian Case," 2009 Int. Conf. Inf. Manag. Eng., pp. 85-89, 2009.

[14] H. M. Park, "The Web Accessibility Crisis of the Korea's Electronic Government: Fatal Consequences of the Digital Signature Law and Public Key Certificate," 2012 45th Hawaii Int. Conf. Syst. Sci., pp. 2319-2328, 2012.

[15] H. Jogiyanto, Analisis dan Desain Sistem Informasi. Yogyakarta: Andi, 2005.

[16] Kristanto, Perancangan Sistem Informasi dan Aplikasinya. Yogyakarta: Gava Media, 2008.

[17] Kusrini and A. Koniyo, Tuntutan Praktis Membangun Sistem Informasi Akuntansi dengan Visual Basic \& Microsoft Sql Server. Yogyakarta: Andi, 2007.

[18] H. Jogiyanto, Analisis dan Desain Sistem Informasi : Pendekatan Terstruktur Teori dan Praktek Aplikasi Bisnis. Yogyakarta: Andi, 1999.

[19] L. B. Wiratmo, N. Irfan, and Kuwatono, "Website Pemerintah Daerah sebagai Sarana Online Public Relations.," J. ASPIKOM, vol. 3, no. 2, pp. 326-339, 2017.

[20] E. A. Sosiawan, "Evaluasi Implementasi E-Government pada Situs Web Pemerintah Daerah di Indonesia: Perspektif Content dan Manajemen," in Seminar Nasional Informatika, 2015, pp. 88-98.

[21] F. Masyhur, "Kinerja Website Resmi Pemerintah Provinsi di Indonesia," PEKOMMAS, vol. 1, no. 17, pp. 9-14, 2014.

[22] KEMKOMINFO, Buku Putih Komunikasi dan Informatika. Jakarta, 2016.

JSIKTI Vol. 1, No. 2, December 2018: $75-86$ 